\title{
The Institutional Supply of China's Participation in the International Monetary System Reform
}

\author{
Yonghui Wang
}

Received: 7 September 2013/Accepted: 9 December 2013/Published online: 18 April 2014

(C) The Author(s) 2014. This article is published with open access at Springerlink.com

\begin{abstract}
There exist dual features of internationalization and regionalization in the current international monetary system, and the U.S. dollar is still in a dominant position in the system. A lack of relevant institutional constraints has led to institutional deficiencies and systematic risks in the international monetary system, and resulted in the frequent financial crises in the world in recent years. As an emerging economy closely related to the current international monetary system, China has responsibilities and obligations to participate actively in international monetary system reform and push forward international monetary system reform through institutional supply.
\end{abstract}

Keywords China - International monetary system · Institutional innovation · Institutional supply

\section{Introduction}

The international monetary system is a relatively broad concept: generally speaking, it usually refers to the sum of the international currency systems, the international financial institutions, and the established international monetary order which is formed from the habits and history of humankind (He 2006, p. 290). The international monetary system generally includes the following: (1) which currency will be used in international communication - the gold standard or inconvertible credit currency; (2) exchange rate arrangements among countries, pegging a currency or allowing exchange rates to be changed according to demand and supply; and (3) how to adjust the imbalance of foreign exchange receipts and payments

\footnotetext{
Y. Wang $(\bowtie)$

Institute of Political Science, Central China Normal University, 152 Luoyu Road, Hongshan District, Wuhan 430079, Hubei, China

e-mail: wyhui0427@163.com
} 
among different countries (Huang 2000, p. 422). Since the East Asian financial crisis in 1997, the different problems triggered by the international monetary system have become the concern of international society. The global financial crisis, which resulted from the sub-prime mortgage crisis of America in 2008, has pushed the reform of the international monetary system to the cusp. Meanwhile, the maladjustment between the current international monetary system and the development of the global real economy has led to a necessity for international monetary system reform (Justin 2012, pp. 2-4).

With the deepening of the reform and opening-up policy, China now has an increasingly strong interdependence with the world; meanwhile, the current international monetary system may also have a substantial impact on China. China's current economy has undergone rapid development, and its GDP was ranked second in the world in 2010. Thus, to ensure the security of national economic development and national finance, China should play an important role in the process of reforming the international monetary system. The global financial crisis may be regarded as a good opportunity for international monetary system reform, and the world may have concerns over how China grasps this opportunity to take part in reforming the international monetary system. How can China find the best solution for reform when the international monetary system is not only related to China itself, but also related to changes in the current international monetary structure?

\section{Institutional Deficiencies in the Current International Monetary System}

Since the Bretton Woods system collapsed in 1976, the international monetary system has entered into the Jamaica system era. ${ }^{1}$ This has simply meant the decline of the U.S. dollar hegemony, the main content of which is the "double hook," But not the end of it. Under the Jamaica system, the international monetary pattern has developed toward the direction of diversification, but the U.S. dollar is still in a dominant position in the current international monetary system.

There also exists the feature of global public goods in the international monetary system (Charles 1973, pp. 56-61).To some extent, the current system dominated by the U.S. may reduce relative transaction costs (Wang 2007, pp. 51-55). A few U.S. scholars and politicians regularly use hegemonic stability theory to provide theoretical support for the U.S. dollar hegemony. The core content of hegemonic stability is that there must be a hegemonic state to maintain a stable international financial order, and the hegemonic state should have superb capability to provide international public goods from which all the states in the international monetary

\footnotetext{
1 In January 1976, the International Monetary Fund (IMF) Council held a meeting in Jamaica's capital Kingston, discussed the terms of the IMF, and signed the "Jamaica agreement." In April of the same year, the IMF Council passed through the second amendment of "Jamaica agreement," meaning that the Jamaica system was established. The core content of the Jamaica system includes diversification of the reserve currency, legalization of floating exchange rates, diversification of international payments, and non-monetization of gold.
} 
system may benefit. However, the hegemonic stability theory does not provide a valid explanation to the changes to the international monetary mechanism. Robert (2005), pp. 88-105 thinks that the hegemonic stability theory has its flaws in three aspects: first, it focuses on the changes of tangible resources, but ignores the fact that the United States' ability to maintain the mechanism does not depend on the possession of tangible resources, but on its confidence in dealing with international financial affairs; second, it fails to recognize the dual characteristics of the U.S.'s powerful position in the international monetary system since 1971; third, the index of GDP, as a measure of power resources, leads to false prophecy upon the collapse of the hegemonic state. At the same time, some practices have proved that there are severe institutional deficiencies in the Jamaica system characterized by the U.S. dollar hegemony, and the following context will make further analysis.

\subsection{The U.S. Dollar Standard of International Monetary System Exacerbated the Imbalance of International Payments}

So far, the U.S. dollar standard of the Jamaican system is that essentially the U.S. dollar has dual identities:sovereign currency, and the international currency standard (Chen and Chen 2010, pp. 56-61). The U.S. dollar standard is a centerperipheral international monetary system: the United States is at its core, while emerging markets and developing countries are on the periphery. There is no doubt that, in this structure, the U.S. dollar has characteristics of a hegemonic currency.

Figure 1 is a concise description of the situation of international resource flows in the current international monetary system. Europe and other developed countries have invested in or bought a great amount of U.S. financial assets, while the U.S. has received a large amount of real capital through the sale of these financial assets. Emerging markets and developing countries mainly sell goods and services to the United States, while the United States uses the U.S. dollar or bonds to buy these goods and services. For this reason, the majority of emerging markets and developing countries have accumulated large amounts of the U.S. dollar reserves, and saved these through buying U.S. Treasury bonds and others. The existing international monetary system has led to a serious imbalance of international payments. Under the existing system, some developing countries may keep the upsurge of the current account surplus and foreign exchange reserves by the United States' persistent current-account deficit, while it is easy to cause the global excess liquidity of the U.S dollar.

Therefore, in lacking an automatic adjustment mechanism to the international balance of payments as well as with the unlimited expansion of the international reserve credit, the Jamaica system has some fundamental shortcomings for avoiding global financial crisis. One paradox of the unlimited expansion of the international reserve credit is that the global adjustment function of the international monetary system and U.S.'s economic growth were aggregated by the U.S. dollar standard, which generally caused the dilemma between interest coordination and cost sharing.

An important performance of the international payments imbalance is the upsurge of peripheral countries' foreign exchange reserves. In recent decades, the 


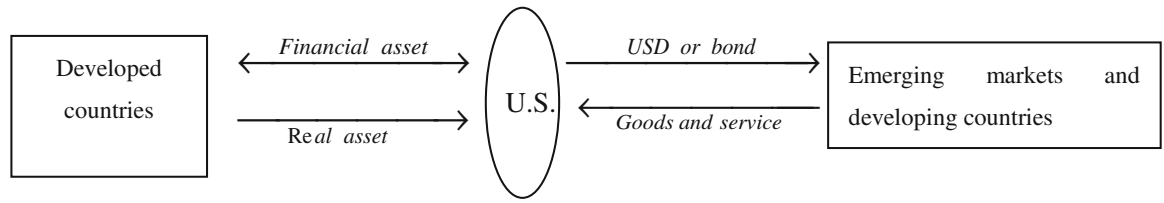

Fig. 1 International resource flows diagram under the existing international monetary system

Table 1 United States' total import and export volume 2000-2010 (unit: million U.S. dollars)

\begin{tabular}{llll}
\hline & $\begin{array}{l}\text { Merchandise } \\
\text { trade deficit }\end{array}$ & $\begin{array}{l}\text { Service } \\
\text { trade deficit }\end{array}$ & $\begin{array}{l}\text { the overall } \\
\text { deficit }\end{array}$ \\
\hline 2000 & -4462.33 & 674.53 & -3787.8 \\
2001 & -4219.80 & 575.86 & -3643.93 \\
2002 & -4573.45 & 548.21 & -4205.24 \\
2003 & -5415.44 & 473.61 & -4941.83 \\
2004 & -6656.31 & 562.86 & -6093.45 \\
2005 & -7358.01 & 696.25 & -7141.76 \\
2006 & -8394.56 & 802.16 & -7592.4 \\
2007 & -8231.92 & 1210.93 & -7020.99 \\
2008 & -8346.52 & 1358.5 & -6988.02 \\
2009 & -5069.44 & 1210.36 & -3749.08 \\
2010 & -6458.77 & 1458.3 & -5000.27 \\
\hline
\end{tabular}

Sources of data http://www.ben.doc.gov

United States has faced wide-ranging and long-lasting deficits of current accounts and capital accounts, and the exact data are shown in Table 1.

Meanwhile, some emerging economies have a high surplus of current accounts (Lilia 2009, pp. 79-89), as represented by China. In addition to China, India, Brazil, and other developing countries' foreign exchange reserves have also experienced rapid growth in recent years. Of course, a country's foreign exchange reserve is not necessarily "the more, the better." According to Development Economics theory, in order to achieve the maximum economic benefit, the economic behavior's marginal cost must equal its marginal revenue. From this viewpoint, when the marginal cost of a country's foreign exchange reserves equals the marginal revenue, the reserve amount is a modest one. In different countries, there may be different ways to measure a country's foreign exchange reserves. This article will take China as an example while using the Agar Wall model to test the appropriate scale of foreign exchange reserves and compare it with China's actual foreign exchange reserves.

The Agar Wall sets up a moderate scale model of the developing countries' foreign exchange reserves:

$$
R=W\left(\lg k+\lg q_{2}-\lg q_{1}\right) / \lg p
$$

where $\mathrm{R}$ represents a moderate scale of foreign exchange reserves, $k$ is the reciprocal of the capital-output ratio, $q_{2}$ is the ratio of imports of productive goods 
to the total output, $q_{1}$ is the import content of the additional capital, and $p$ is the probability of deficit. However, considering the low elasticity of demand for China's import and export and that the balance-of-payments adjustment is slow, we will adopt the revised Agar Wall model to measure the appropriate scale of China's foreign exchange reserves. The model is as follows:

$$
R=W\left(\lg k+\lg q_{2}-\lg q_{1}\right) / \lg p+\alpha D+\beta I+A
$$

where $\mathrm{D}$ is the balance of foreign debts, $I$ represents the accumulated balance for FDI, $A$ represents the Risk Development Fund, $\alpha$ represents the external debt service ratio, and $\beta$ represents the foreign direct investment margin. This article will use the revised Agar Wall model to estimate our moderate scale in foreign exchange reserves for each year of 2000-2011. The raw data used for calculation come from the China Financial Yearbook and China Statistical Yearbook of China Taiwan database. Based on international experience, $\alpha$ is generally defined as between 12 and $18 \%, \beta$ is generally defined as between 10 and $15 \%$, and $A$ is generally defined as between $5 \% \mathrm{R}$ and $10 \% \mathrm{R}$. In the model $\mathrm{k}$ can be expressed as the total investment of fixed assets/GDP, $q_{1}$ represents the imported primary products/new fixed asset investment, and $q_{2}$ represents the imported primary products/GDP. Since China's 34 years of reform and opening up, there has been an increase of trade deficit up to a total of nine times, and the probability of occurrence is $9 / 34$. Moreover, in 1985, there was the largest trade deficit in China with the amount of the deficit up to $\$ 14.9$ billion, and so we can set $\mathrm{W}=149$.

Foreign reserves in moderate scale should be in some range, and the upper limit $\mathrm{R}_{\max }$, the lower limit $\mathrm{R}_{\min }$, and the value in $\mathrm{R}_{\min }$ can be respectively expressed as

$$
\begin{gathered}
R_{\max }=\left[W\left(\lg k+\lg q_{2}-\lg q_{1}\right) / \lg p+18 \% D+15 \% I\right] / 0.9 \\
R_{\min }=\left[W\left(\lg k+\lg q_{2}-\lg q_{1}\right) / \lg p+12 \% D+10 \% I\right] / 0.95 \\
R_{\text {mid }}=\left(R_{\max }+R_{\min }\right) / 2
\end{gathered}
$$

Table 2 shows the estimated values of $k, q_{1}$, and $q_{2}$ and during 2000-2011, the moderate scale of China's foreign exchange reserves is shown in Table 3.

As seen from Table 3, since 2000, China's foreign exchange reserve has grown rapidly. Its value in 2011, compared with 2000 , is up by $1821.3 \%$. Meanwhile, the actual foreign currency reserves are above the upper limit of the moderate scale of foreign exchange reserves, exceeding 21.318 billion in 2000, 430.841 billion in 2004, 16.95767 billion in 2008, and 2814.242 billion in 2011. These data sufficiently show that China's foreign exchange reserves are increasing too fast and far beyond a reasonable range.

Developing countries lack mature financial markets, and their huge foreign exchange reserves usually outflow back to developed countries by buying financial assets, thus driving down long-term interest rates in developed countries' financial markets (Zhang and Guo 2009, pp. 46-49). The future monetary system may be a mixed system, the balance of international payments of which may be achieved through a variety of regulatory mechanisms and determined by all the participating countries (Dominick 2000, pp. 133-148). While, in the current situation, it is 
Table 2 1985-2011: $k, q_{1}$, and $q_{2}$ estimated values

\begin{tabular}{lllr}
\hline Year & $k$ & $q_{1}$ & $q_{2}$ \\
\hline 2000 & 0.332 & 1.263 & 0.039 \\
2001 & 0.339 & 0.881 & 0.035 \\
2002 & 0.361 & 0.649 & 0.034 \\
2003 & 0.409 & 0.499 & 0.044 \\
2004 & 0.441 & 0.651 & 0.061 \\
2005 & 0.483 & 0.661 & 0.066 \\
2006 & 0.521 & 0.707 & 0.071 \\
2007 & 0.557 & 0.672 & 0.074 \\
2008 & 0.573 & 0.710 & 0.086 \\
2009 & 0.669 & 0.665 & 0.059 \\
2010 & 0.707 & 0.654 & 0.072 \\
2011 & 0.660 & 0.701 & 0.081 \\
\hline
\end{tabular}

Table 3 Modest foreign exchange reserves during 2000-2011 in China. (Unit: 100 million U.S. dollars)

\begin{tabular}{lllll}
\hline Years & $\begin{array}{l}\text { Upper limit of } \\
\text { foreign exchange }\end{array}$ & $\begin{array}{l}\text { Lower limit of } \\
\text { foreign exchange }\end{array}$ & $\begin{array}{l}\text { Middle value of } \\
\text { foreign exchange }\end{array}$ & $\begin{array}{l}\text { Actual foreign } \\
\text { exchange }\end{array}$ \\
\hline 2000 & 1442.56 & 1091.25 & 1266.91 & 1655.74 \\
2001 & 1535.45 & 1139.20 & 1337.33 & 2121.65 \\
2002 & 1583.52 & 1156.19 & 1369.86 & 2864.07 \\
2003 & 1636.89 & 1164.51 & 1400.70 & 4032.51 \\
2004 & 1790.91 & 1256.44 & 1523.67 & 6099.32 \\
2005 & 1977.12 & 1367.96 & 1672.54 & 8188.72 \\
2006 & 2155.89 & 1477.66 & 1816.77 & 10663.44 \\
2007 & 2361.97 & 1601.56 & 1981.77 & 15282.49 \\
2008 & 2502.63 & 1685.55 & 2094.09 & 19460.3 \\
2009 & 2784.75 & 1869.88 & 2327.31 & 23991.52 \\
2010 & 3167.73 & 2101.09 & 2634.41 & 28473.38 \\
2011 & 3669.06 & 2418.53 & 3043.79 & 31811.48
\end{tabular}

Note lower limit, upper limits, and middle value of foreign exchange reserves are derived from the model calculations; the actual foreign exchange reserves data are from the State Administration of Foreign Exchange website.(http://www.safe.gov.cn)

difficult for the U.S. dollar-dominated international monetary system to get rid of the "Triffin dilemma", therefore, it easily results in the imbalance of international payments.

\footnotetext{
${ }^{2}$ The Triffin dilemma means the conflict of economic interests, which arises between short-term domestic and long-term international objectives when a national currency also serves as a world reserve currency. The dilemma of choosing between these objectives was first identified in the 1960s by BelgianAmerican economist Robert Triffin. He pointed out that the country, currency of which serves as the global reserve currency, must be willing to supply the world with an extra supply of its currency to fulfill world's demand for these foreign exchange reserves, and thus cause a trade deficit.
} 


\subsection{Frequent Fluctuations of International Exchange Rates are a Major Incentive of Global Financial Risk}

There does not exactly exist a binding international regime in the current international monetary system, and it does not have a clear arrangement about which countries are free to choose a fixed or a floating exchange rate (Oliver et al. 2011, pp. 3-4). Since the establishment of a floating exchange rate system in 1973, the exchange rate which may make a greater fluctuation is an incontrovertible increase to transaction costs, and affects international trade at the same time (Oliver et al. 2011, pp. 776-785). Adopting a floating exchange rate system is thought to be a measure to suppress the outbreak of financial crisis by many economists. Compared with the previous fixed exchange rate, under a floating exchange rate system, there is no reduction of government intervention in the foreign currency market and the international currency reserves (Dominick 1998, pp. 375-415). Under the floating exchange rate system, each country's currency exchange rate may fluctuate greatly, which not only happens in developing countries, but also among the developed countries.

From Table 4, we can see that in 3 years, the exchange rate among several currencies fluctuated dramatically, especially the exchange rate between the USD and JPY. During the half year, i.e., from June to December of 2007, the fluctuation in the rate between the USD and JPY reached $8.9 \%$, and in comparison with December 2007, the scope of its fluctuation reached $24.3 \%$ in December 2010. Exchange rate is one of the most important links in the international monetary system, because it not only provides price signals to market participants, but also sets a key factor to global rational resource allocation. A floating exchange rate has exacerbated the turmoil of the international financial market, resulting in the overflow of currency arbitrage, interest arbitrage, and other short-term speculative activities. Simultaneously, the volatility and deviation of the main international currencies' exchange rates have brought tremendous negative effects to emerging economies (Xiu 2008, pp. 5-9). According to some critics of emerging economies, the United States may take advantage of the floating exchange rate system but not undertake obligations of keeping the stability of exchange rate, simultaneously gaining benefits from reducing debts through the U.S. dollar's depreciation. As the floating exchange rate system in

Table 4 Spot exchange rates between certain groups of currencies

\begin{tabular}{lllll}
\hline & peso/lille & Malaysian dollar/THB & USD/JPY & USD/EUR \\
\hline 2007.06 .01 & 0.1776 & 9.6862 & 122.0500 & 0.7433 \\
2007.12 .01 & 0.1647 & 9.1540 & 111.2300 & 0.6831 \\
2008.06 .01 & 0.1576 & 9.9764 & 105.4900 & 0.6426 \\
2008.12 .01 & 0.1723 & 9.8452 & 93.1670 & 0.7927 \\
2009.06 .01 & 0.1741 & 9.8224 & 96.5700 & 0.7060 \\
2009.12 .01 & 0.1338 & 9.8125 & 86.6690 & 0.6662 \\
2010.06 .01 & 0.1424 & 9.8440 & 91.2400 & 0.8124 \\
2010.12 .01 & 0.1375 & 9.5839 & 84.1800 & 0.7700 \\
\hline
\end{tabular}

Source According to the relevant data collected from http://cn.reuters.com 
the international monetary system has been doubted increasingly, it is urgent for all nations to explore a new and reasonable exchange rate system.

\subsection{International Monetary System Dominated by Few Big Powers has led to Irrational Allocation of Resources in International Society}

On the background of economic globalization, the quantitative easing (QE) monetary policy in the United States has caused the overflow of global liquidity; meanwhile, the allocation of global savings may not be optimized, and these are closely related to institutional deficiencies of the international monetary system (Yan 2011). In recent years, one of the goals of the U.S. dollar's continuous depreciation has been to downsize the U.S.'s domestic trade deficit, while the U.S. dollar's depreciation has brought adverse impact on some countries' exports. From the perspective of developing countries including China, because of the international U.S. dollar standard, the United States may influence global resource allocation through adjusting its monetary policy, which also makes other countries, especially developing countries, become risk takers as a result of the U.S.'s economic volatility. In general, developing countries' interests face severe threats; they might fall victims to the monetary policy adjustment by some dominating countries in the international monetary system. Although some developing countries hope to get rid of this unfavorable situation by taking some measures, under the current system, however, they face great challenges to bring out significant benefits.

Besides, due to the advantages of the developed countries' economic strength, the developed countries may gain more when making the policy game with developing countries. Therefore, in the decision-making of international monetary system, the developed countries may take a complete dominant position, while developing countries can only take subordinate positions, passively accepting developed countries' arrangements.

Figure 2 shows a simple complete information dynamic game picture. If $\mathrm{a}>\mathrm{e}>\mathrm{c}>\mathrm{g}$, and $\mathrm{b}>\mathrm{d}$, then the Nash Equilibrium in this refined game model is (reform system, accept; if $\mathrm{e}>\mathrm{a}>\mathrm{g}>\mathrm{c}$, and $\mathrm{f}>\mathrm{h}$, then the Nash Equilibrium in this refined game model is (keep system, accept. Although it is a simple dynamic game

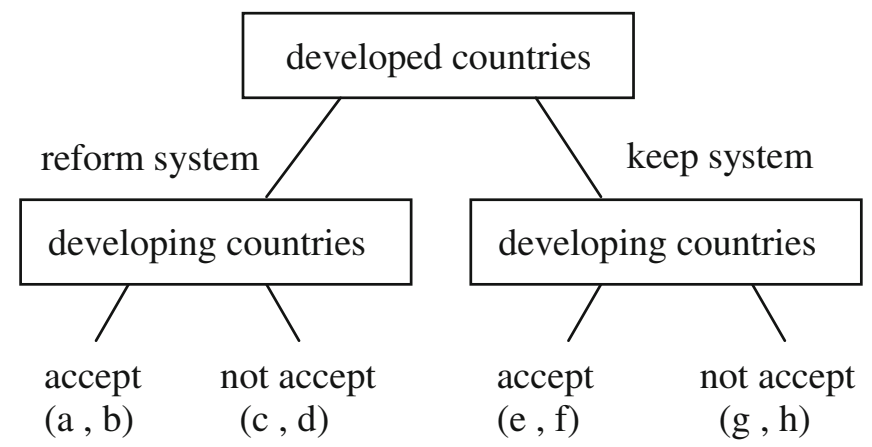

Fig. 2 The game between developed countries and developing ones in international monetary system reform 
picture, from it, we can see that the developed countries have the priority option of reforming or keeping the existing international monetary system, while the developing countries can only passively accept the developed countries' arrangements. Furthermore, it proves that developing countries suffer disadvantaged positions in the current international monetary system, and there is some internal impetus from developing countries to push forward international monetary system reform.

\section{The Basic Path of China's Participation in Institutional Innovation of the International Monetary System}

With the deepening of economic globalization, the interdependence between China and the world is also being strengthened. It is increasingly apparent that the current international monetary system has brought forth adverse impact on China. The global financial crisis in 2008 also made China suffer a huge shock. Although China was the first country which shook off the crisis, the crisis still made China rethink the current international monetary system. In recent years, China has actively participated in the institutional innovation of the international monetary system, and determined what is required to build a more just and rational international monetary system. The following text, from the perspective of institutional supply, will analyze the process of China's participation in the international monetary system reform.

\subsection{To Promote Actively the Diversification of the International Monetary} System and the RMB's Internationalization

Although there exist many hidden perils in the U.S. dollar hegemony, it is too difficult to find a proper international reserve currency to replace the U.S. dollar in the current international monetary system. Nonetheless, China still advocates the diversification of the international monetary system as well as the RMB's internationalization. In March 2009, Zhou Xiaochuan, the governor of the People's Bank of China, proposed to establish a kind of super-sovereign reserve currency, which may not be connected with a sovereign state, to replace the U.S. dollar and avoid the inherent flaws caused by sovereign credit (Zhou 2009). This idea was rapidly favored by Russia, Brazil, and some other countries after it was proposed. However, as a goal of long-term reform, this proposal did not have great practical significance. Therefore, the Chinese government did not officially propose to establish a super-sovereign currency, but took certain actions to promote the diversification of the international monetary system instead. In the future, the international monetary system may emerge just as Mundell (2000, pp. 327-340) described, as "three stable islands in the global finance," a tripartite situation of the U.S. dollar, euro, and one kind of Asian currency. Besides the process of promoting the diversification of the international reserve currency, China is also promoting the internationalization of the RMB. It is not only the demand of economic development in China, but also the demand of balancing the development of the international monetary system. Under the process of the RMB's internationalization, China needs patience and should carry it out step by step, and make it 


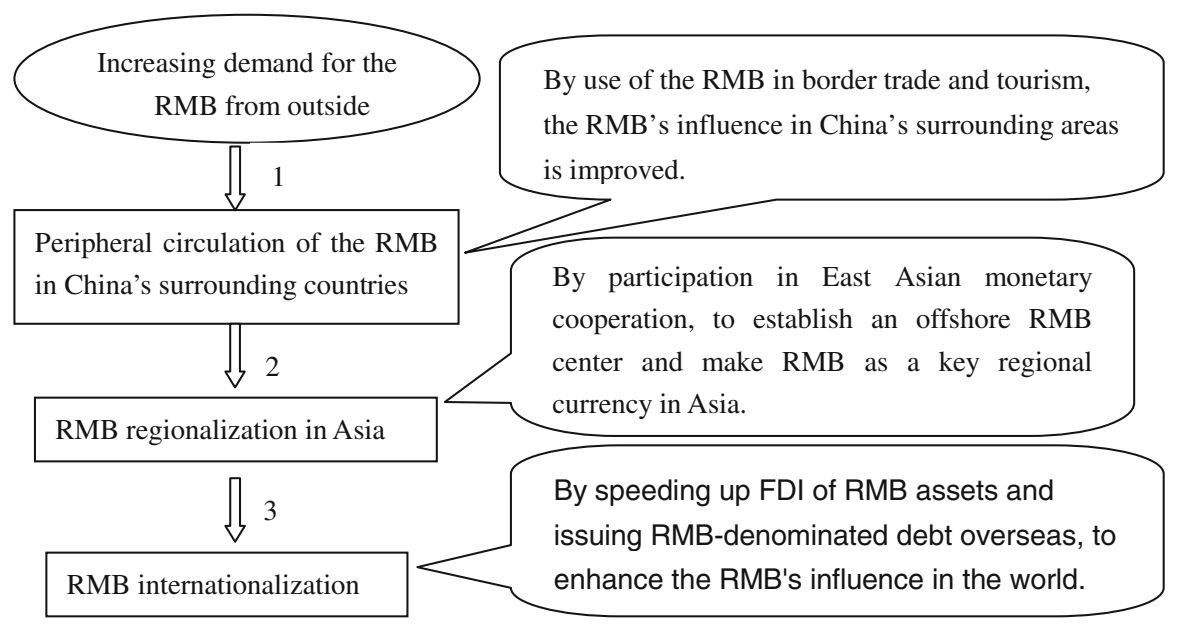

Fig. 3 The basic path of RMB's internationalization

appropriate to China's economic developing stage. The basic process of the RMB's internationalization is seen in Fig. 3

About the internationalization of a currency, so far, there is no clear definition in the academic circles. This article tends to regard the RMB's internationalization as a process from the current regional reserve currency to the world's main reserve currency. It can be predicted that the internationalization of RMB will never be smooth, and it may be blocked by other international currencies; for instance, in East Asia, the yen is a strong competitor of RMB to be the international currency. How may the RMB achieve the goal of internationalization effectively? In the following, this article will use the asymmetric evolutionary game model to analyze the challenges for RMB's internationalization. It is supposed that RMB is a potential international currency, China is set up as $\mathrm{X}$, and the other countries which own the international currency as Y.

In the model of Table 5, $i$ indicates the benefit of cooperation, $a_{1}$ indicates the loss of the $\mathrm{X}$ against the confrontation, $a_{2}$ indicates the loss of the $\mathrm{Y}$ against the confrontation, and $a_{1}>a_{2}>i>0$. If both $\mathrm{X}$ and $\mathrm{Y}$ take confrontation strategy, and the probability of success or failure is $1 / 2$ each, then the gains are, respectively. $\frac{i-a_{1}}{2}, \frac{i-a_{2}}{2}$. If $\mathrm{X}$ and $\mathrm{Y}$ take cooperation strategy, then both parties have half chance of gain, but no loss. If the cooperation strategy encounters confrontation strategy, then the confrontation strategy gains, but the cooperative strategy does not.

To X, the probability of strategy $M_{1}$ to be chosen is $\alpha$, and the probability of strategy $M_{2}$ to be chosen is $1-\alpha$. To Y, the probability of strategy $M_{1}$ been chosen is $\beta$, and the probability of strategy $M_{2}$ to be chosen is $1-\beta$. Then,

The dynamic equation for $\mathrm{X}$ is $\frac{d \alpha}{d t}=\alpha(1-\alpha)\left(\frac{a_{1}-i}{2}-\frac{a_{1}}{2} \beta\right)$.

The dynamic equation for $\mathrm{Y}$ is $\frac{d \alpha}{d t}=\beta(1-\beta)\left(\frac{a_{2}-i}{2}-\frac{a_{2}}{2} \alpha\right)$

With these two dynamic equations, you can get five equilibrium points simultaneously: $\left(\alpha^{*}=0, \beta^{*}=0\right),\left(\alpha^{*}=1, \beta *=1\right),\left(\alpha^{*}=0, \beta=1\right),\left(\alpha^{*}=1, \beta^{*}=0\right)$, and $\left(\alpha^{*}=1-\frac{i}{a_{2}}, \beta^{*}=1-\frac{i}{a_{1}}\right)$. Through the analysis of the characteristic values of these 
Table 5 Asymmetric evolutionary game model

\begin{tabular}{llll}
\hline & & $\mathrm{Y}$ & \\
\cline { 3 - 4 } & & Cooperation & Confrontation \\
\hline $\mathrm{X}$ & Cooperation & $\left(\frac{i}{2}, \frac{i}{2}\right)$ & $(0, \mathrm{i})$ \\
& Confrontation & $(\mathrm{i}, 0)$ & $\left(\frac{i-a_{1}}{2}, \frac{i-a_{2}}{2}\right)$ \\
\hline
\end{tabular}

five equilibrium points, we can see that the first and the second equilibrium points are unstable, while the third and the fourth equilibrium points tend to be stable, and the fifth equilibrium point is a mixed strategy of Nash Equilibrium.

From Fig. 4 , the final convergence of equilibrium points are $\left(\alpha^{*}=0, \beta=1\right)$, $\left(\alpha^{*}=1, \beta^{*}=0\right)$ and $\left(\alpha^{*}=1-\frac{i}{a_{2}}, \beta^{*}=1-\frac{i}{a_{1}}\right)$. Taking the actual situation into consideration, the initial situation that falls into the region $\mathrm{D}$ has a larger probability, and thus two parties will eventually converge to the evolutionary stable strategy, that is, $\left(\alpha^{*}=1, \beta^{*}=0\right)$, and $\mathrm{X}$ will take the cooperation strategy, and $\mathrm{Y}$ will take the confrontation strategy. The actual situation can confirm this analysis; some countries with strong currencies tend to take a confrontation strategy to impede other currency to be an international currency. At the present stage, the United States has monetary power in the international monetary system. In the reform of the international monetary system, it also holds an attitude of noncooperation, and may not wish to see the RMB or other currency become an international currency. Therefore, the United States has constantly criticized the RMB exchange rate in recent years. In March 2013, 101 senators of the United States proposed legislation to claim China as a "currency manipulator." Therefore, in order to achieve its goal of the RMB's internationalization, China may not look to any country which has dominant monetary power, but to strengthen cooperation with other countries on the basis of "increase of China's strength." At the present stage, China has made significantly useful attempts to promote the RMB's internationalization, and accomplished some achievements, such as RMB circulation and RMB reserves in neighboring countries. In Hong Kong, Taiwan, and Singapore, non-deliverable forward market and some other offshore RMB derivatives appear in international financial markets. In April 2005, the European Central Bank increased some currencies including the RMB in the euro exchange rate system guidance. In December 2006, the Philippines took the RMB as a central bank reserve currency, and it was first time for the RMB to become another country's reserve currency. By the end of 2010, in Mongolia, the RMB has reached a share of $60 \%$ in payment, settlement, and reserve. In 2010 September, the Malaysian central bank also began to buy RMB-denominated bonds as a part of its foreign exchange reserves (Gao 2011, pp. 134-135). In the Shanghai Cooperation Organization and the surrounding countries of China, the RMB is used more frequently and widely, and the external conditions of RMB's internationalization becomes more and more mature.

Of course, we understand that it will be a long process of promoting the RMB's internationalization and the diversification of the international monetary system 


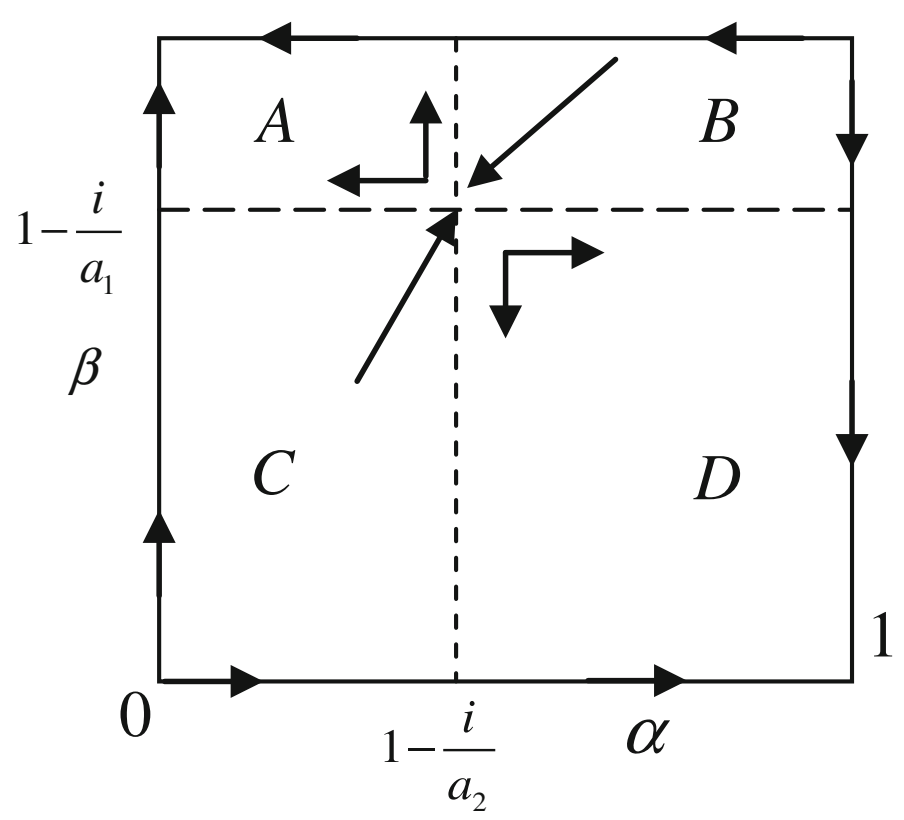

Fig. $4 \mathrm{X}$ and $\mathrm{Y}$ asymmetric evolutionary model schematic diagrams

(Pen 2010, pp. 46-49). It also needs China's great efforts to make some appropriate reform in the RMB' s exchange rate formation mechanism, the balance-of-payments adjustment mechanism, and the monitoring and management mechanisms.

\subsection{To Vigorously Promote the Process of East Asian Monetary Cooperation}

For developing countries including China, the core task is to change the international U.S. dollar standard in the process of current international monetary system reform. At the present stage, according to the theory of optimum currency area (or Optimal Currency Area, OCA) which was proposed first by Robert Mundell, East Asian countries may take a unified regional currency, for stabilizing exchange rate system, obtaining the balance of international payments, and so on. The subprime mortgage crisis makes Asian countries realize that there exist internal defects and potential risks from the U.S. dollar standard. In July 2012, the 17th session of the Executives' Meeting of East Asia-Pacific Central Banks (EMEAP) ${ }^{3}$ focused on Asian-Pacific monetary cooperation, and one of its main targets was to prevent the negative externalities of the U.S. dollar standard.

\footnotetext{
${ }^{3}$ The Executives' Meeting of East Asia-Pacific Central Banks (EMEAP) is a cooperative organization of central banks and monetary authorities in the East Asia and Pacific region. Its primary objective is to strengthen the cooperation among its members. It comprises the central banks of 11 economies: Reserve Bank of Australia, People's Bank of China, Hong Kong Monetary Authority, Bank of Indonesia, Bank of Japan, Bank of Korea, Bank of Malaysia, Reserve Bank of New Zealand, Bank of Pilipinas, Monetary Authority of Singapore, and Bank of Thailand. See http://www.pbc.gov.cn/publish/diaochatongjisi/3765/ index.html.
} 


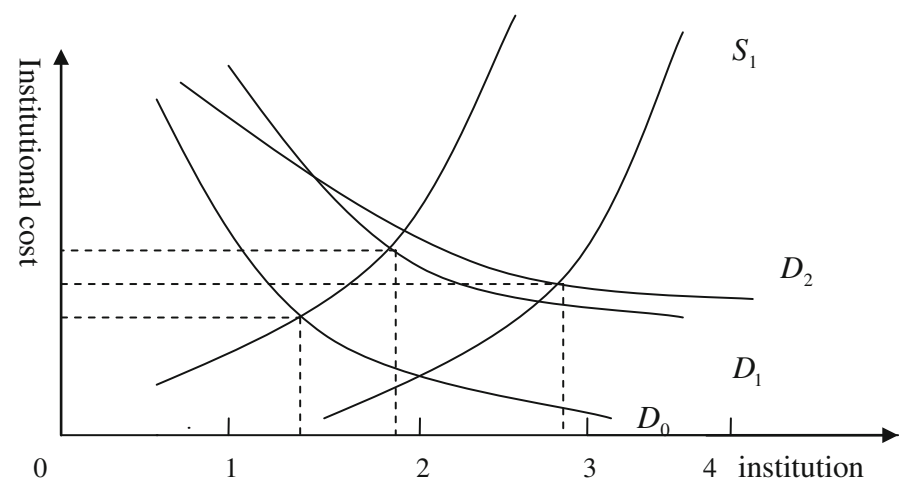

Fig. 5 The institutional equilibrium model of monetary cooperation in East Asia

To prevent the negative externalities of the U.S. dollar standard, the best way perhaps is to speed up the East Asian monetary integration. This article will describe a simple analysis from the perspective of the institutional change of East Asian monetary cooperation. One principle of Institutional Economics is that the formation of a mechanism lies in demand factors. The changes of East Asian monetary cooperation may be attributed to demand factors which resulted from the East Asian financial crisis, East Asian countries' economic development, rigidity of the international monetary system, globalization and regionalization, and so on.

As we can see from Fig. 5, the initial system seems relatively steep, with low elasticity. Under this condition, it will generate higher system costs to promote system changes. The financial crisis of East Asia and development demand of each country will drive the demand curve to shift from $D_{0}$ to $D_{1}$; in this process, it may also produce a number of complementary system arrangements, but the cost of system arrangement is relatively high. Hence, the supply curve $S$ is relatively steep, and lacks flexibility. In this case, only the supply curve moves to the right, from $D_{0}$ to $D_{2}$, it may cause changes of traditional mechanism, and establish a new system.

Currently, the East Asian monetary cooperation has made some substantial progress in Chiang Mai Initiative, Asian currency unit, Asian bond market, and regional exchange rate cooperation. Under the " $10+3$ " framework, East Asian countries have strengthened the exchange data of capital flow with each other, and by the end of 2012, China has signed bilateral currency swap agreements with 18 countries, with the total amount of over 1.6 trillion RMB (Pbc, 2013). In practice, China's vigorous efforts in promoting the East Asian monetary cooperation have made certain partial influence on enhancing Asia's financial status, changing the situation of the U.S. dollar standard in international monetary system, and reconstructing the competitive and cooperative international currency system.

\subsection{To Build Various Mechanisms of Multilateral Consultation}

In order to push forward the current international monetary system reform, it is not enough to rely on a country's strength, but needs the efforts of all the countries in 
the world, especially of some emerging markets and developing countries. The most typical representatives of China's participation in the changeable consultation mechanism to advance international monetary system reform are G20 and "BRICS."4 In December 1999, finance ministers and central bank governors of the G20 held the first informal meeting in Berlin, who established of the G20 mechanism. This is the first time that emerging countries were involved in the discussion of the international financial governance structure. The establishment of the $\mathrm{G} 20$ is seen as a crucial step toward international financial governance structure reform (Randall 2001). Some unreasonableness of the current international monetary system has already drawn the attention of the members of G20, and the members declared that the international monetary system reform is necessary (Eric 2011). As a representative of developing countries, in each summit, China had actively advocated the establishment of a new international financial order. But we must also be aware that the existing G20 mechanism is not enough to assume the responsibility of establishing the new international economic order, but it needs long-term hard efforts for big powers to achieve that goal (Tan and Zhang 2009). Therefore, BRICS mechanism may be an effective complementarity for G20 mechanism. The BRICS countries, the total area of which is about $30 \%$ of the world and the total population of which is about $43 \%$ of the world's population (Stats 2010), include the global major developing countries and emerging markets exerting powerful influence in the world.

Through participation in various international multilateral mechanisms, as shown in Fig. 6, including G20, China tries to promote the diversity of the international monetary system, improve the reserve currency issuing regulatory mechanism, and maintain the relative stability of the exchange rate of major reserve currencies to create favorable conditions for international monetary system reform. Different from G7 or G8 consisting of the developed countries, G20 mechanism has allowed developing countries to participate in global economic governance, and also provides some major developing powers with a platform to solve international affairs, represented by the fact that China and India are increasingly involved in the decision-making of international economic affairs. However, the urgent tasks of participants in the G20 mechanism in the near term are to collectively promote the reform of the international monetary system, offer a comprehensive platform to carry out international economic policy coordination for various national interests, and achieve the target of "imbalance controlment" and "dollar risk restraint."

\subsection{To Actively Promote IMF and World Bank's Structural Reforms}

The International Monetary Fund (IMF) is one of the world's most important financial institutions, with the task of promoting international monetary cooperation, and playing a significant role in the consultation and collaboration of international monetary issues. However, the IMF has not accomplished its task well. In 2008, the

\footnotetext{
4 The 2001 American Goldman Sachs first proposed the "BRIC" concept, including the world's four largest emerging market countries (Brazil, Russian, Indian, and China); in December 2010, the four countries agreed to accept South Africa formally to join the "BRIC" mechanism, and "BRIC" was renamed "BRICS."
} 


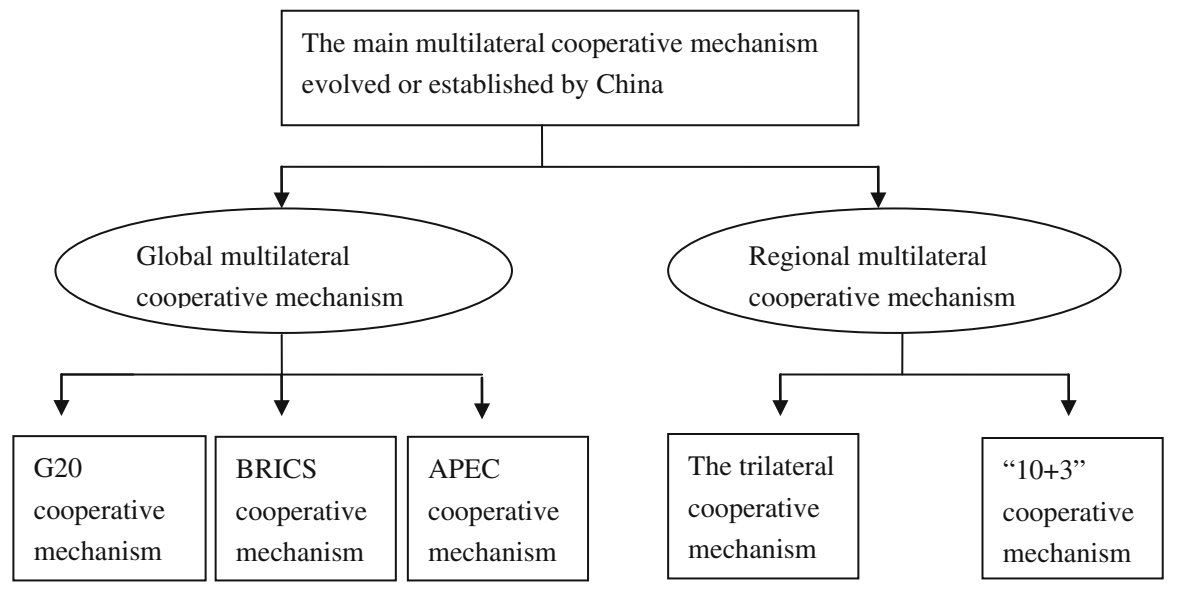

Fig. 6 Concise schematic diagram of China's participation in the multilateral cooperation mechanism

IMF had the responsibility to prevent the global financial crisis, but failed. the IMF has taken some internal reform, but the goal is not to solve its unfair governance structure. The decision-making power of the IMF is still held by some wealthy countries. The reform of the IMF's governance structure has become a worldwide concern, especially by emerging markets and developing countries. China is a strong supporter as well as an active participant in the IMF reform, which has already made a substantial step. The Chinese government has repeatedly expressed willingness to buy the bonds issued by the IMF. In June 2010, ministers and central bank governors of G20 reached a historic agreement on the IMF quota reform, and determined to transfer over $6 \%$ share of the IMF to the emerging economies. But, at the same time, the United States' share is more than $15 \%$, which means that the United States still has the veto power in the IMF, and the status of the U.S. dollar hegemony in the IMF has not been shaken. Therefore, it requires a more significant institutional innovation in the IMF for shifting more IMF shares and the vote rights to emerging markets (Chen and Chen 2010, pp. 56-61).

Like the International Monetary Fund, the World Bank is also a globally important international economic organization, which plays a significant role in the world's economic development. The World Bank reform focuses on decision-making mechanism reform. As one of the world's largest financial organizations, the decision-making mechanism of the World Bank should be institutionalized and democratic in functioning. But, under the current situation, there exists serious political interference in the decision-making of the World Bank, and both the development strategy and decision-making procedure of the IMF are controlled by a few developed countries. China appealed frequently that the World Bank needs to be reformed at the G20 conference, and received wide support and response from developing countries. In practice, there were achieved some initial results in the World Bank's reform. On April 25, 2010, the World Bank Development Committee passed a voting scheme by transferring more vote rights from the developed countries to developing ones. For some of the exact changes of the IMF vote rights distribution, see 


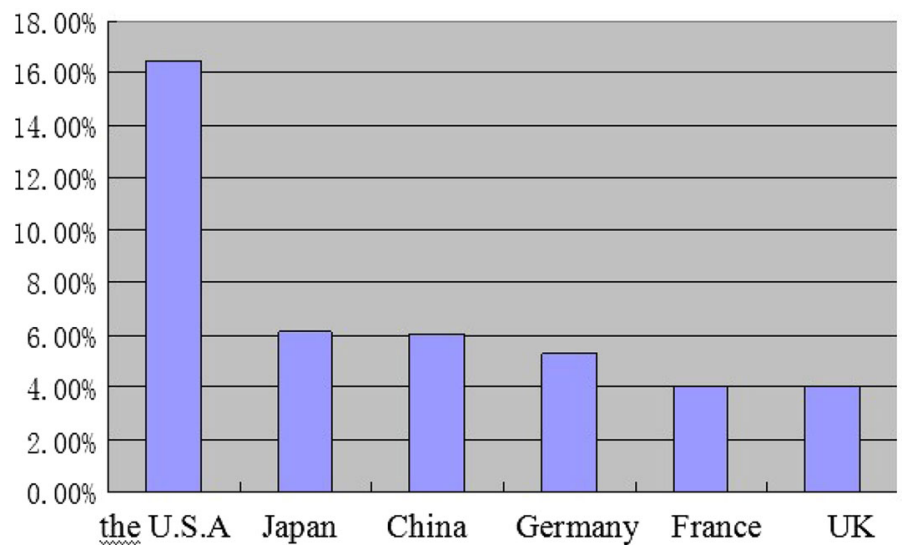

Fig. 7 IMF voting rights distribution after reform. source: www.xinhuanet.com

Fig. 7. Of course, this is only a small step toward World Bank's reform; however, the voting procedure, supervision mechanism, and some other aspects of the World Bank also have much room for reform. For China, what it expects of the World Bank is not its arbitrary nature, but an organization with the ability to represent the interests of developing countries, having fair decision-making mechanisms in place.

Under the scarcity of funds, some scholars argue that countries with a large amount of foreign exchange reserves and huge potential for economic growth may not be restricted by the so-called international rules (liu 2009, p. 28). But, in the present situation, the international monetary system has certain constraints on China's economic development. For China, it is an appropriate time to participate in the IMF reform and the World Bank reform, and it is a good opportunity to promote China's status in international society through international monetary system's reform.

\section{Prospect of China's Participation in the International Monetary System Reform}

In recent years, China has taken active part in the reform of the international monetary system. Meanwhile, China has taken many concrete measures, and accomplished some achievements in institutional innovation of the international monetary system. From the practices, it seems clear that China holds a strong will to reform the international monetary system. We may have some prospects of China's participation in the international monetary system reform as follows:

\subsection{Chinese Elements will be Increased in the International Monetary System}

There is no doubt that the current international monetary system is dominated by the United States and the other developed countries. But with China's rapid economic growth and great progress in domestic mechanism, the RMB's internationalization tends to be strengthened. As the RMB's internationalization is gradually improved, 
the RMB's influence in the world is to be enhanced, and it also means that the RMB will play a more important role in the international monetary system. In the reforms of the IMF, the World Bank, and other major global financial institutions, China's involvement will continue to increase, and as an opaque goal, China not only wants to be a performer of global financial rules, but also a maker.

\subsection{China Faces Greater External Pressure in the International Monetary System}

As Chinese elements in the international monetary system have been greatly enhanced, China will face much more external pressures than ever. Take the example of RMB exchange rate: at the present stage, the United States and the European Union have put great pressure on RMB's appreciation, and China faces huge pressure to make the RMB's appreciation. At the same time, as China shares more voice in the IMF, the World Bank, and other global financial institutions, China has to shoulder more international responsibilities and obligations, which will undoubtedly make China face more external pressures and challenges.

\subsection{Continuous Institutional Adjustment of International Monetary System will be made Between the Traditional Powers and Emerging Powers}

In recent years, China, India, Brazil, and other emerging countries have continued to rise in the world, and these emerging countries have growing influence upon the international monetary system. In addition to their own striking economic development, they have also created a variety of cooperation mechanisms which may offer opportunities for more developing countries to speak in international economic affairs. One of the most successful examples is the "BRICS" Mechanism. The BRICS countries have currently implemented the cooperation mechanism of currency settlement to reduce risk from interest rate fluctuation of the U.S. dollar. At the same time, it is beneficial for BRICS countries to promote respective statuses in the international monetary system by the rapid growth of foreign trade and investment, and a variety of financial services with high efficiency among BRICS members. Therefore, since the subprime mortgage crisis happened, Europe and the United States have suffered the economic recession with high unemployment, while the BRICS countries may keep fast economic growth, and play an important role in global economic recovery.

With the rapid rise of emerging countries as well as with increasing unity and cooperation among emerging countries, it can be predicted that the traditional great powers dominating the international monetary system will face more challenges than ever, and emerging countries represented by China will share a more significant voice in the international monetary system.

\section{Conclusion}

From the gold standard system to the Bretton Woods system, each of the international monetary systems has played an important role in a certain historical 
period, and been destroyed by its own shortcomings. The existing international monetary system still belongs to the continuation of the Jamaica system, and still it cannot break away from the traditional shortcomings. In the Jamaica system, the United States has established a set of international rules which treat the U.S. dollar as standard currency and serve the United States for rational logic of national interest. While for China and many other developing countries, those international rules may neglect developing countries' rational demands, and be regarded as the internal defects of the Jamaica system. For the internal defects of the Jamaica system, it is necessary to make current international monetary system reform by China and other developing countries.

In order to ensure the healthy development of China's economic and financial securities, China must play a more active role in international monetary system's reform, especially in respect of the institutional supply. However, in the short term, the international monetary system may not be significantly reformed; the U.S. dollar hegemony will be maintained for a long period; and the international monetary system will be dominated by the traditional powers for a long time. To promote the reform of the international monetary system, the most feasible way for developing countries is to focus on economic development, and continuously strengthen unity and cooperation among themselves. For China, the main task now is to keep the high speed of economic growth, and complete "soft landing" in economic development. ${ }^{5}$ Though China has a strong desire to promote international monetary system's reform and the RMB's internationalization, it is important for China to explore an optimal way to keep China's long-term sustainable development under the current international monetary system and share common interests with various countries. It also requires China to cooperate with the world, including both emerging countries and the developed countries.

Open Access This article is distributed under the terms of the Creative Commons Attribution License which permits any use, distribution, and reproduction in any medium, provided the original author(s) and the source are credited.

\section{References}

He, Zhang. 2006. International finance (the third version). Beijing: China Financial Publishing House. Huang, Da. 2000. Money and banking. Beijing: Renmin University of China press.

Justin, Yifu, Lin, Sbabrokb, Fardoust, David, Rosenblatt, 2012. Reform of the international monetary system: a jagged history and uncertain prospects. Policy working paper 6070 .

Charles, Kindleberger. 1973. The World in depression 1929-1939. London: The Penguin Press.

Wang, Yonghui. 2007. The U.S. dollar factor in monetary cooperation in East Asia. Southeast Asian Studies, no. 1.

Robert Owen Keohane. 2005. After hegemony: cooperation and discord in the world political economy. Princeton: Princeton University Press.

Chen, Jiangsheng, and Chen, Zhaoming. 2010. The international monetary system reform and RMB internationalization. Journal of Chinese Communist Party's Central Academy 1: 15-16.

\footnotetext{
5 Soft landing refers to that, over a period of over-expansion, the national economy smoothly declines to moderate growth, usually by a country's appropriate economic policies.
} 
Lilia, Costabile. 2009. Current global imbalance and the Keynes plan: a Keynesian approach for reforming the international monetary system. Structural Change and Economic Dynamics 20: 79-89.

Zhang, Jiashu, and Guo, Yao. 2009. Under the global financial crisis, transformation of the international monetary system and the process of internationalization of the RMB." Theory Horizon 7: 11.

Dominick, Salvatore. 2000. The present international monetary system: problems, complications, and reform. Open Economics Review 11: 133-148.

Oliver, Bush, and Katie, Farrant, and Michelle, Wrighe. 2011. Reform of the international monetary and financial system." Financial Stability Paper, December.

Dominick, Salvatore. 1998. International monetary and financial arrangements: present and future. Open Economics Review 7: 375-416.

Xiu, Jing. 2008. Changes of the international monetary system and china's strategy analysis. Business Studies 6: 9.

Yan, Ting. 2011. Reform to the international monetary system:the future belongs to SDR?China Business News, May 18.

Zhou, Xiaochuan. 2009. Reflections on the reform of the international monetary system. http://www.pbc. gov.cn/.

Mundell, Robert A. 2000. A reconsideration of the 20th century. The American Economic Review 90(3): $327-340$.

Gao, Jing. 2011. The strategy of RMB internationalization under the background of international monetary system reform. Academic Forum 10: 22.

Pen, Xingyun. 2010. The evolution of the international monetary system and the diversification process of China's selection-the evolution analysis of international monetary system which based on 'currency power. Chinese Review of Financial Studies 5: 13.

Randall, Germain. 2001. Global Financial Governance and the Problem of Inclusion. Global Governance 7: $411-412$.

Eric, Santor. 2011. The international monetary system: An assessment and avenue for reform. Autumn.

Tan, Zhe, and Zhang, Yuyan. 2009. G20 is a turning point in world and China. Chinese Social Sciences Today, April 16.

Liu, Jingqi. 2009. The feasibility and mode of China's participating in IMF reform." Commercial Times.

Yonghui Wang is an associate Professor of Institute of Political Science at Central China Normal University, and postdoctoral researcher of Economics at Huazhong University of Science and Technology. This article is some phased achievement of author's research project of "China's participation in the international system reform," funded by 2012 China Postdoctoral Fund (the funding ID: 2012M511600) and 2011 National Social Science Foundation of China (Grant No. 10AZD029). 